\title{
Antibacterial Activity and Chemical Composition of Turkish Propolis
}

\author{
Nevin Keskin ${ }^{\mathrm{a}, *}$, Selçuk Hazir ${ }^{\mathrm{a}}$, K. Hüsnü Can Baser ${ }^{\mathrm{b}}$ and Mine Kürkçüoglu ${ }^{\mathrm{b}}$ \\ a Hacettepe University, Faculty of Science, Department of Biology, 06532 Beytepe, \\ Ankara-Turkey \\ b Anadolu University, Medicinal and Aromatic Plant and Drug Research Centre (TBAM), \\ 26470 Eskisehir-Turkey \\ * Author for correspondence and reprint requests \\ Z. Naturforsch. 56c, 1112-1115 (2001); received May 4/August 23, 2001 \\ Propolis, Hive Product, Antibacterial Agent \\ The antibacterial activities of propolis samples have been examined in vitro, according to \\ the principles accepted for the determination of a similar activity of antibiotics with the use \\ of solid and liquid media. It has been found that propolis extracts showed antibacterial activ- \\ ity through a range of commonly encountered gram positive cocci ( $S$. aureus, beta hem. \\ Streptococus), but had weak activity against gram negative bacteria (E. coli, P. aeruginosa). \\ GC/MS analysis showed that propolis samples contain a variety of chemical compounds in- \\ cluding aromatic compounds, fatty acid esters and sesquiterpenes.
}

\section{Introduction}

Propolis is a hive product, collected by honey bees from the gum of different types of trees (e.g., poplar, birch, willow) and plants containing resins, waxes, flavonoids and some "impurities" (e.g., pollen, wood, fragments of bees) (Ghisalberti, 1979; Ackerman, 1991; Bankova et al., 1992). Bees mix this balsam with substances derived from pollen and different types of active enzymes. Propolis is a building and protective material. Bees use propolis to plug the gaps of the hive and more importantly to impede the decomposition of the creatures which have been killed by the bees following an invasion of the hive (Kaal, 1991). Also the high relative humidity, optimum temperature and abundant presence of nutrients in the hives would result in very rapid propagation of moulds and bacteria, without the presence of propolis. Its antimicrobial potency keeps the growth of microbes under control (Szente and Szejtli, 1987; Meresta and Meresta, 1980; Kivalkina, 1976; Bankova et al., 1995).

The use of propolis for treatment of many diseases has been known in folk medicine since the earliest times (Ghisalberti, 1979; Meresta and Meresta, 1980). More detailed studies on the therapeutic properties of propolis were performed in the last thirty five years (Villanueva et al., 1964; Lindenfelser, 1967; Meresta and Meresta, 1983 and 1986; Brumfitt et al., 1990; Grange and Davey,
1990; Zumla and Lulat, 1989; Dobrowolski et al., 1991). Apparently, propolis is very selective in the way it attacks pathogenic bacteria as well as mycoses and virus infections which might be dangerous to human beings. Because of its selectivity normal bacteria such as those of the flora which perform a vital function in our digestive system are not affected. Propolis does not create any harmful sideeffects nor do bacteria build up resistance to it. Propolis is now found in tooth pastes, chocolates, shampoos, creams, tablets, etc. and the world production has increased to several thousand $\mathrm{kg}$ per year. The composition of propolis may vary depending on its geographical origin (Ackerman, 1991; García-Viguera et al., 1992; García-Viguera et al., 1993; Markham et al., 1996; Borčić et al., 1996; Bankova et al., 1998). We have investigated in vitro two different samples of propolis for their potential antimicrobial activities against different bacteria and chemical composition of these samples by GC/MS.

\section{Experimental}

\section{Plant material}

Two natural native propolis samples collected from two different areas of the Marmara region of Turkey (Balikesir and Istanbul) were used in experiments. Each raw material which consisted of a block of brown waxy material was kept in a 
refrigerator for $48 \mathrm{~h}$ then it was ground in a grinder.

\section{Preparation of the extract}

Propolis was extracted according to Meresta and Meresta, (1980), with some modification: Powdered propolis was treated with $96 \%$ ethyl alcohol and kept at $37^{\circ} \mathrm{C}$ for $24 \mathrm{~h}$. The supernatant was decanted, then a mixture of ethyl alcohol and ethyl ether in proportion $1: 1, \mathrm{v} / \mathrm{v}$ was poured over the rest and again it was kept at $37^{\circ} \mathrm{C}$ for $24 \mathrm{~h}$. After the second supernatant was decanted, ether was poured over the rest and it was kept at $3{ }^{\circ} \mathrm{C}$ for $24 \mathrm{~h}$. Finally, after the third supernatant was decanted, ethyl acetate was poured over the rest and kept at $37^{\circ} \mathrm{C}$ for $24 \mathrm{~h}$. After the last supernatant decantation all the extracts were mixed and filtered through filter paper. Next, waxy substances soluble in the solvents mentioned above were precipitated by centrifugation and the liquid part was again filtered through filter paper. The clear solution of propolis extracts obtained in this way was evaporated at low pressure to eliminate solvent residues.

\section{Simultaneous distillation-extraction (SDE)}

After the extracts were evaporated, the dark, sticky, brown substance of propolis was dissolved in $70 \%$ ethyl alcohol. Volatiles of the propolis extract were worked up by Likens-Nickerson simultaneous distillation-extraction (SDE) method in pentane (Sandra and Bicchi, 1987).

\section{GC/MS analysis of propolis samples}

The propolis volatiles were analyzed by GC/MS using a Hewlett-Packard GC-MSD system. An Innowax FSC column $(60 \mathrm{~m} \times 0.25 \mathrm{~mm}$ i.d. with $0.25 \mu \mathrm{m}$ film thickness) was used with helium as the carrier gas. GC oven temperature was kept at $60{ }^{\circ} \mathrm{C}$ for $10 \mathrm{~min}$. and programmed to $220^{\circ} \mathrm{C}$ at a rate of $4{ }^{\circ} \mathrm{C} / \mathrm{min}$., and then kept constant at $220^{\circ} \mathrm{C}$ for $10 \mathrm{~min}$. and programmed to $240^{\circ} \mathrm{C}$ at a rate of $1{ }^{\circ} \mathrm{C} / \mathrm{min}$. Split flow was adjusted to $50 \mathrm{ml} / \mathrm{min}$. The injector temperature was at $250{ }^{\circ} \mathrm{C}$. MS were taken at $70 \mathrm{eV}$ in the EI mode. Mass range was from $m / z 35$ to 425 . Library search was carried out using Wiley GC/MS Library and TBAM Library of Essential Oil Constituents (Ardrey et al., 1983;
Jennings and Shibamoto, 1980; Masada, 1975; McLafferty and Stauffer, 1988; Swigar and Silverstein, 1981).

\section{Microbial strains}

Escherichia coli, Pseudomonas aeruginosa, Staphylococcus aureus and beta-hemolytic Streptococci (all of them were clinical isolates) obtained from Hospital of Hacettepe University, Department of Bacteriology were used.

Antibacterial activities of particular propolis extracts were determined by assessment of the minimal inhibitory concentration (MIC) and that of the minimal bactericidal concentration (MBC). The determinations of the MIC were performed in solid medium of $\mathrm{pH} 6.8$ (nutrient agar and blood Agar) while that of the MBC was carried out in liquid medium with $\mathrm{pH}$ 6.8/nutrient broth). Propolis extracts were added in arithmetical progression. The concentration of propolis in the media was expressed in $\mu \mathrm{g}$ per $\mathrm{ml}$. The media were inoculated with bacteria and were kept at $37^{\circ} \mathrm{C}$ for 18-24 h. Liquid media were inoculated with a $18 \mathrm{~h}$ culture. The bacterial density of the culture was determined spectrophotometrically at $490 \mathrm{~nm}$ according to Mc Farland's scale using buffered saline solution. Liquid media were inoculated with 104 cells per ml of medium. Solid media were inoculated with an 18 hour liquid culture.

\section{Results and Discussion}

To determine antibacterial activities, two different propolis extracts were tested against Gram negative (E. coli and P. aeruginosa) and Gram positive ( $S$. aureus and beta hemolytic Streptococci) species. The MIC and MBC values of propolis extracts are shown in Table I.

GC/MS analysis of propolis volatiles are shown in Table II.

For the selected bacteria studied, propolis samples inhibited better the growth of $S$. aureus and beta hemolytic Streptococci than gram (-) bacteria (E.coli and P. aeruginosa). Previous studies also reported that gram negative bacteria were less susceptible showing lower minimal inhibitory concentration (MIC) than gram positive strains (Szente and Szejtli, 1987; Lindenfelser, 1967; Dobrowolski, et al., 1991). The bactericidal dose of the studied extracts was as a rule, approximately twice as large 
Table I. The MIC ${ }^{\mathrm{a}}$ and $\mathrm{MBC}^{\mathrm{b}}$ values of two different samples of propolis.

\begin{tabular}{lclccc}
\hline Region & $\begin{array}{c}\text { Amount per } \mathrm{ml} \\
{[\mathrm{mg} / \mathrm{ml}]}\end{array}$ & $\begin{array}{l}\text { Microorganism } \\
\text { tested }\end{array}$ & $\begin{array}{c}\mathrm{MIC} \\
{[\mu \mathbf{g} / \mathbf{m l}]}\end{array}$ & $\begin{array}{c}(\mathrm{MBC}) \\
{[\mu \mathbf{g} / \mathbf{m l}]}\end{array}$ & $\begin{array}{c}\text { Ratio of } \\
\text { MIC to MBC }\end{array}$ \\
\hline Balikesir & \multirow{2}{*}{310} & E. coli & 1705 & 3100 & $1: 1.8$ \\
& & P. aeruginosa & 1705 & 3100 & $1: 1.87$ \\
& & S.aureus & 175 & 310 & $1: 1.77$ \\
Istanbul & \multirow{2}{*}{160} & B. hem. Strep & 175 & 310 & $1: 1.77$ \\
& & E. coli & 88 & 160 & $1: 1.8$ \\
& & P. aeruginosa & 9 & 160 & $1: 1.8$ \\
& & S.aureus & 88 & 16 & $1: 1.7$ \\
& & B. hem. Strep & & 160 & $1: 1.8$ \\
\hline
\end{tabular}

a Minimal inhibitory concentration.

b Minimal bactericidal concentration.

Table II. Chemical composition of propolis samples.

\begin{tabular}{lcc}
\hline Compounds & $\begin{array}{c}\text { Propolis from } \\
\text { Istanbul (\%) }\end{array}$ & $\begin{array}{c}\text { Propolis from } \\
\text { Balikesir }(\%)\end{array}$ \\
\hline 3-Methyl-2-butenol & 16.6 & - \\
Ethyl decanoate & - & 1.1 \\
Ethyl benzoate & - & 3.0 \\
Diethyl succinate & 22.9 & - \\
Ethyl decanoate & - & 1.5 \\
Calamenene & - & $<0.1$ \\
Ethyl-3-phenyl propionate & 2.3 & 14.6 \\
Phenylethyl alcohol & 3.8 & - \\
(E)-Ethyl cinnamate & - & 1.8 \\
$\gamma$-Eudesmol & 3.9 & 10.9 \\
$\alpha$-Eudesmol & 7.1 & 20.4 \\
$\beta$-Eudesmol & 11.8 & 29.6 \\
Ethyl hexadecanoate & 14.7 & 2.6 \\
Decanoic acid & - & 1.2 \\
Ethyl oleate & 7.1 & 5.8 \\
\hline
\end{tabular}

as the bacteriostatic dose (Table I) which proves propolis as a highly effective and useful material.

GC/MS analysis showed propolis samples contained a variety of chemical compounds including aromatic components, fatty acid esters, cinnamates and sesquiterpenes (calamenene, eudesmol) (Ta- ble II). Many studies have shown that fatty acid esters, phenolic compounds, terpenoid compounds and cinnamic acid are the main propolis constituents and some of them possess antibacterial activity (Bankova et al., 1992; Wollenweber et al., 1987; Greenaway et al., 1988; Kujumgiev et al., 1993) Propolis collected from hives in Balikesir was more chemically diverse (12 compounds) than the material collected from Istanbul (fewer than 10). But it showed a weaker antibacterial activity than the Istanbul extract. The Istanbul sample had three chemical components (3-methyl-2 butenol, diethyl succinate and phenyl-ethyl alcohol) different from the Balikesir sample. The greater activity of the Istanbul sample on bacteria than the Balikesir sample may be attributed to its slightly different chemical composition.

The experiments revealed that there can be minor differences in antibacterial activity of propolis extracts depending on the region from which the stock comes. First of all this is due to nectar flows and the presence of a specific flora within the area of bee circulation. 
Ackerman Th. (1991), Fast chromatographic study of propolis crudes. Food Chem. 42, 135-138.

Ardrey R. E., Brown C., Allan A. R., Bal T. S. and Mofffat A. C. (1983), An Eight Peak Index of Mass Spectra of Compounds of Forensic Interest. Scottish Academic Press, Edinburgh.

Bankova V., Boudourova-Krasteva G., Popov S., Sforcin J. M. and Cunha Funari S. R. (1998), Seasonal variations in essential oil from Brazilian propolis. J. Essent. Oil Res. 10, 693-696.

Bankova V. P., Christov R., Kujumgiev A. Marcucci M. C. and Popov S. (1995), Chemical composition and antibacterial activity of Brazilian propolis. Z. Naturforsch. 50c, $167-172$.

Bankova V., Christov R., Stoev G. and Popov S. (1992), Determination of phenolics from propolis by capillary gas chromatography, J. Chromatogr. 607, 150-153.

Borčić I, Radonić A. and Grzunov K. (1996), Comparison of the volatile constituents of propolis gathered in different regions of Croatia. Flavour Fragr J. 11, $311-313$.

Brumfitt W., Hamilton-Miller J. M. T. and Franklin I. (1990), Antibiotic activity of natural products. I. Propolis. Microbios 62, 19-22.

Dobrowolski J. W., Vahora S. B., Sharma K., Shahsa Naghi S. A. H. and Dandiya P. C. (1991), Antibacterial, antifungal, antiaroebic, antiinflammatory and antipyretic studies on propolis bee products. J. Ethnopharmacol. 35: 1, 77-82.

García -Viguera C., Greenaway W. and Whatley F. R. (1992), Composition of propolis from two different Spanish regions. Z. Naturforsch. 47c, 634-637.

García -Viguera C., Ferreres F. and Tomas-Barberan F. A. (1993), Study of Canadian propolis by GC-MS and HPLC. Z. Naturforsch. 48c, 731-735

Ghisalberti E. (1979), Propolis: a review. Bee world 60 (2), 59-84.

Grange J. M. and Davey R. W. (1990), Antibacterial properties of propolis. Royal Soc. Med. 83, 159-160.

Greenaway W, Scaysbrrok T and Whatley F. R. (1998), Composition of propolis in Oxfordshire, U. K. and its relation to poplar bud exudate. Z. Naturforsch. 43c, $301-305$.

Jennings W. and Shibamoto T. (1980), Qualitative Analysis of Flavour and Fragrance Volatiles by Glass Capillary Gas Chromatography. Academic Press, London.

Kaal J. (1991), Natural Medicine from Honey Bees (Apitherapy). Kaal's Printing House Amsterdam. Holland.
Kivalkina V. P. (1976), Fractionation of propolis and investigation of the antimicrobial activity of the fractions. In: Mezd. Kongres Pchelov., Grenoble 1975. Apimondia, Bucharest, p.222.

Kjumgiev A., Bankova V., Ignatova, A. and Popov S. (1993), Antibacterial activity of propolis, some of its components and their analogs. Pharmazie 48, 785786.

Lindenfelser L. A. (1967), Antibacterial activity of propolis. Am. Bee J. 107 (3): 90-92, 130-131.

Markham K. R., Mitchell K. A., Wilkins A. L., Daldy J. A. and Lu Y. (1996), HPLC and GC-MS identification of the major organic constituents in New Zealand propolis. Phytochemistry 42, 205-211.

Masada Y. (1975), Analysis of Essential Oils by GC/MS. Hirokawa Publishing, Tokyo.

McLafferty F. W. and Stauffer D. B. (1988), The Wiley/ NBS Registry of Mass Spectral Data. Wiley, New York, pp. 1-7.

Meresta L. and Meresta T. (1980), Effect of pH on bacteriocidal activity of propolis. Bull. Vet. Inst. Pulawy. 24 (1-4), 21-25.

Meresta L. and Meresta, T. (1983), Research on in vitro antibacterial activity of propolis extracts. Bull. Vet. Inst. Pulawy 26 ( 1-4), 77-80.

Meresta L. and Meresta T. (1986), Antibacterial activity of flavonoid compounds of propolis. occuring in Flora of Poland. Bull. Vet. Inst. Pulawy. 28-29 (1-4), 61-63.

Sandra P. and Bicchi C. (eds. by). (1987), Capillary Gas Chromatography in Essential Oil Analysis. Huethig Verlag, Heidelberg, pp. 89-91.

Szente L. and Szejtli J. (1987), Formulation of propolis with $\beta$-cyclodextrin. Actopharm. Technol. 33 (4). $218-221$.

Swigar A. A. and Silverstein R. M. (1981), Monoterpenes: Infrared, Mass, $1 \mathrm{H}$ NHR and 13C NMR Spectra and Kovats Indices. Aldrich Chemical Co. Inc., Wisconsin.

Villanueva V. R., Bogdanosky D., Barbier M., Gonnet M.and Lavie, P. (1964), Sur I' identification de la 3,57 trihydoxy flavone (galagine) a' partir de la propolis. Ann. Inst. Pasteur, Paris 106, 292-302.

Wollenweber E., Asakawa Y, Schillo D., Lehmann V. and Weigel H. (1987), A novel caffeic acid derivative and other constituents of Populus bud excretion and propolis, Z. Naturforsch. 42c, 1030-1034.

Zumla A. and Lulat A. (1989), Honey, a remedy rediscovered. J. R. Soc. Med. 82, 384-385. 